\title{
Metabolomics affirms traditional alcoholic beverage raksi as a remedy for high- altitude sickness
}

\author{
Soumya Majumder, Arindam Ghosh, Sourav Chakraborty, Sumedha Saha and Malay Bhattacharya* (D)
}

\begin{abstract}
Raksi, a fermented distilled alcoholic beverage, is an ethnic drink consumed in high altitude regions of Singalila Ridge of the Himalayas and in adjoining high altitude places in Nepal, northern and north eastern part of India and Tibetan plateau. Like jaanr, tongba, nigar, chhyang, and other fermented ethnic beverages, raksi is considered as an element of ethnopharmacology of high altitude with claims of medicinal properties. An ethnobiological survey was done in the study area prior to collection and identification of raksi samples. In this research, two raksi samples (khokim raksi and chimphing raksi) of Singalila Ridge of the Himalayas were investigated by metabolite profiling using gas chromatography-mass spectrometry analysis. Results of the experiment showed presence of several respiratory protective, cardioprotective, neuroprotective, anti-inflammatory, and antioxidant components which have properties to prevent various high altitude illnesses. Moreover, large quantities of bioactive terpenoids, fatty acid derivatives, coumarins, and peptides were detected whose chemotaxonomy and biosynthesis pathways were further studied. This metabolomics investigation not only affirmed Raksi as a remedy for high-altitude sickness but also helped in understanding the importance of this type of ethnic foods in high altitude ethnoecology. This research on raksi in the fields of ethnobiology and metabolomics is a cumulative approach which has opened the door for in-depth investigations on similar ethnic foods. However, further experiments on raksi are surely needed in ethnobiology, microbiology, biochemistry, and food technology.
\end{abstract}

Keywords: High altitude, Raksi, Ethnoecology, Ethnic beverage, GC-MS, Metabolomics

\section{Introduction}

Elements of human lifestyle, i.e., habitation, clothing, and food habits, are the components that represent ethnic identity of a society. This ethnic identity may differ depending on the region one lives, its geography, weather, and other environmental conditions. The altitude of a region also plays a great role by influencing human activities because altitude controls the environment affecting human lifestyle, precisely, the food that is grown and consumed by the inhabitants of that region. These habits may also differ depending on the age and ability

\footnotetext{
* Correspondence: malaytsnbu@gmail.com

Molecular Biology and Tissue Culture Laboratory, Department of Tea Science, University of North Bengal, Rajarammohanpur, Siliguri, Darjeeling 734013,
} India

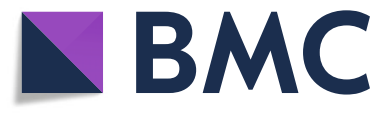

(- The Author(s). 2021 Open Access This article is licensed under a Creative Commons Attribution 4.0 International License, which permits use, sharing, adaptation, distribution and reproduction in any medium or format, as long as you give

appropriate credit to the original author(s) and the source, provide a link to the Creative Commons licence, and indicate if changes were made. The images or other third party material in this article are included in the article's Creative Commons licence, unless indicated otherwise in a credit line to the material. If material is not included in the article's Creative Commons licence and your intended use is not permitted by statutory regulation or exceeds the permitted use, you will need to obtain permission directly from the copyright holder. To view a copy of this licence, visit http://creativecommons.org/licenses/by/4.0/. to process the components of daily needs for consumption. Moreover, ethnicity and food is more dependent over average digestion capability and physical ability of the group of individuals to process the food available in that particular region. An important portion of the world's population lives at high altitude where daily lifestyle, food production, food availability, food requirements, and food habits are seen to be completely different and assiduous, unlike the rest of the world. In a review article, Picon-Reategui [1] provided information on the food and nutrition of high-altitude populations. According to the study, both food production and availability are definitely tied up to altitude, weather condition, soil, and other environmental factors. Relations between food habits and high altitude were further 
described by many scientists and ethnobiologists. Ethnoecology is the scientific study of how different groups of people living in different regions understand the ecosystems around them. This study also helps us to understand how a society or group of people accepts their surrounding environment or conceptualizes and gets acclimatized with their ecological system [2]. So, according to this principle of ethnoecology, high altitude food habits are distinct just to help locals, tourists, or visitors of high altitudes get acclimatized with the surrounding environment, to stay well and get recovered from highaltitudinal sicknesses like hypoxia, fatigue, dizziness, loss of appetite, sleep problems, headache, weakness, acute mountain sickness, vertigo, peripheral edema (swelling of hands, feet, and face), nose bleeding, and cardiovascular diseases. Kayser [3] described the effect of high altitude on nutrition where high altitudinal ailments like hypoxia, gastroenterological (digestion) problem, weight loss, and anorexia nervosa and symptoms like nausea, vomiting, and loss of appetite were mentioned. Anand et al. [4] described this altitude specific health issues with main focus on gastrointestinal problems. Not only ethnic foods or beverages but also local medicinal herbs and plant organs of a region are also considered as elements of that region's ethnoecology. Ethnoecology is cross-cultural where interrelation between people and their environments are studied [5] with ethnic foods, beverages, and ethno-medicines as key components. Like every other region of the world, high altitude ethnoecology exhibits a rational relationship between its people and their ethnic food habits (food/beverage or other ethno-medicines) which directly or indirectly help a group of people to endure the weather conditions.

Ethnoecology of Singalila Ridge of the Himalayas (the high altitude place in between Darjeeling, Sikkim, and Nepal, i.e., our study area) is very distinctive and enriched with plenty of ethnic food habits where jand or jaanr, raksi or rakshi, nigar, chhyang or chhaang, etc. are mentioned as Nepalese and Tibetan ethnic fermented cereal-based alcoholic beverages [6]. Settlements of human ethnic groups (mainly Nepalese) are found in Singalila National Park and adjoining hills. High altitude places like Tumling (2949 m), Phatak (2992 m), Jaubari $(2900 \mathrm{~m})$, Gairibans $(2625 \mathrm{~m})$, Kaiyakatta $(2879 \mathrm{~m})$, Batasay (2971 m), Kalipokhari (3100 m), Bikheybhanjyang $(3200 \mathrm{~m})$, Sandakphu (3626 m), and Phalut (3600 m) are the main villages of Singalila Ridge. Other settlements are also found in the buffer zone of Singalila (at approx. $2300 \mathrm{~m}$ altitude), i.e., Rammam, Siri, Gurdung, Samanden, and Gorkhey [7]. Interestingly, fermentation knowledge and practice have been considered as an intimate part of food and beverage management in high altitude regions since ancient ages which are actually considered as a part of ethnicity of high altitude regions in the world. Fermentation is a process which is followed to preserve food, especially where availability of important nutritious food is a matter of stress. Fermentation helps increase shelf-life of processed or harvested food material where beneficial microorganisms are used. Major fermented foods of high altitude regions of the Himalayas (Darjeeling, Sikkim, and Nepal) are fermented legume products (kinema, masauyra), fermented dairy products (chhurpi, chhu/sheden, philu, somar, etc.), fermented vegetables (gundruk, sinki, Khalpi, Mesu, etc.), fermented cereal products (selroti), fermented meat/fish products and alcoholic beverages like chhaang and raksi [6]. These homemade fermented foods and beverages are considered as ethnoecological components of the mentioned region for being acclaimed as medicinally beneficial to native people or visitors against a lot of high-altitude sickness.

Raksi or rakshi (also pronounced as roxy) is one of those locally fermented traditional food, a distilled alcoholic beverage, which have been used as a medicinal and regular beverage by Tibetan, Nepali, and other ethnic group of people living in high altitudes of the Himalayas (parts of Nepal, northern and north eastern part of India and Tibetan plateau). It is a home-made beverage produced from different grains where millet or rice is used as the main substrate. Raksi is strong and highly astringent in flavor and taste that gives a burning sensation in the digestive tract during consumption [8]. Microbes involved in fermentation of raksi are mainly fermentative yeasts, saccharifying mold, and lactic acid bacteria [9] Drop of $\mathrm{pH}$ or increase of acidity during fermentation is reported in raksi which is expected due to occurrence of organic acids as fermentation metabolites. Alcohol concentration of raksi is reported as 11 to $13 \%$ [9] which is quite acceptable as a regular beverage in high altitudes. Raksi is a very popular homemade liquor in Tibet and in high altitudes of Nepal, Darjeeling (West Bengal), and Sikkim, and is also brewed at almost every household in villages of Singalila, not only for their own consumption but also for selling as it is also very popular among the tourists [7]. The liquor is required in various religious rituals and social events performed by Nepalese and Tibetan Society. Raksi is also ranked as 41 st in the CNN's list of World's 50 most delicious drinks [8].

Raksi, chyang, jand, etc. are well documented in the field of ethnoecology along with some health claims, but there is a lack of proper scientific research on it. Ray et al. [10] prepared chyang in laboratory and performed biochemical analysis of it but raksi is scientifically undiscovered as it has not been significantly studied. The ethnomedicinal claim of this high-altitude medicinal drink should be properly evaluated. Therefore, the main aim of the study was to analyze the biochemical composition and biological activities of two different types of raksi by 
using metabolomics as a tool. In this research, we have analyzed the metabolites (by GC-MS analysis) of two different types of raksis, i.e., khokim raksi and chimphing raksi sipped in Singalila Ridge (the highest altitude region of Darjeeling Himalaya).

\section{Materials and methods}

\section{Study area and ethnobiological survey}

A fieldwork was conducted in the trekking routes (orthodox trekking route of Singalila Ridge, i.e., Dhotrey-Tonglu-Tumling-Gairibans-Kalipokhari-

Bikheybhanjyang-Sandakphu-Phalut) of Singalila $\mathrm{Na}-$ tional Park located in Darjeeling, India, and Indo-Nepal border area (Fig. 1) to collect samples of raksi and identify them by local inhabitants. The local inhabitants or participants of this ethnobiological survey were 55 males and 45 females (24 to 91 years of age groups). Among participants, $68 \%$ were regular raksi consumers and all of the participants were ethnic Nepalese (belong to Lepcha and Nepali communities) who lived in villages of Singalila ridge, i.e., Tonglu (5\%), Tumling (14\%), Gairibans (20\%), Kalipokhari (17\%), Bikheybhanjyang (29\%), Sandakphu (11\%), and Phalut (4\%).

\section{Sample collection and preparation}

Two different fresh samples of locally brewed raksi (khokim raksi and chimphing raksi) were collected from a very old (50 years) and famous traditional raksi selling shop at Bikheybhanjyang $\left(27^{\circ} 05^{\prime} 32^{\prime \prime} \mathrm{N} 88^{\circ} 00^{\prime} 47^{\prime \prime} \mathrm{E}\right.$, Fig. 2). In between Kalipokhri village $(3100 \mathrm{~m})$ and Sandakphu (3626 m, the highest peak of the ridge as well as of the state of West Bengal, India), Bikheybhanjyang $(3200 \mathrm{~m})$ is located (Fig. 3) and reported as one of the oldest human settlements in Singalila National Park [7].

Samples of raksi were collected in sterilized laboratory glass bottles (Fig. 4) to avoid microbial contamination and kept inside the ice box and taken to laboratory. Sample preparation for GC-MS analysis was done following the method of Majumder et al. [11] with slight modification. One milliliter of each sample was dissolved in $1 \mathrm{ml}$ of methanol (Merck) overnight to prepare methanolic (50\%) extracts of khokim raksi (KR) and chimphing raksi (CR). Methanol was taken as solvent depending on some facts, like, it is the widely used and ideal most solvent (compared to other organic solvent) for extraction of biochemicals, and polarity of methanol as an organic solvent shows closeness with that of water or ethanol which are primary solvents of any edible beverage [11].

\section{GC-MS analysis}

Following the research protocol of Majumder et al. [11, 12], metabolite profiles and metabolomics of compounds from different biosynthesis pathways of KR and CR samples were analyzed using GC-MS based metabolomics. GCMS-QP2010 Plus (Shimadzu Co., Japan) with DB-5 fused-silica capillary column $(0.25 \mu \mathrm{m}$ film thickness, $0.25 \mathrm{~mm}$ internal diameter, and $30 \mathrm{~m}$ of length) was used in this research. Analysis was performed by split injecting (with a ratio of 20:1) $1 \mu \mathrm{l}$ of each sample (KR and $\mathrm{CR})$. Injection temperature was $260{ }^{\circ} \mathrm{C}$ and interface temperature was $270{ }^{\circ} \mathrm{C}$. Ion source temperature was

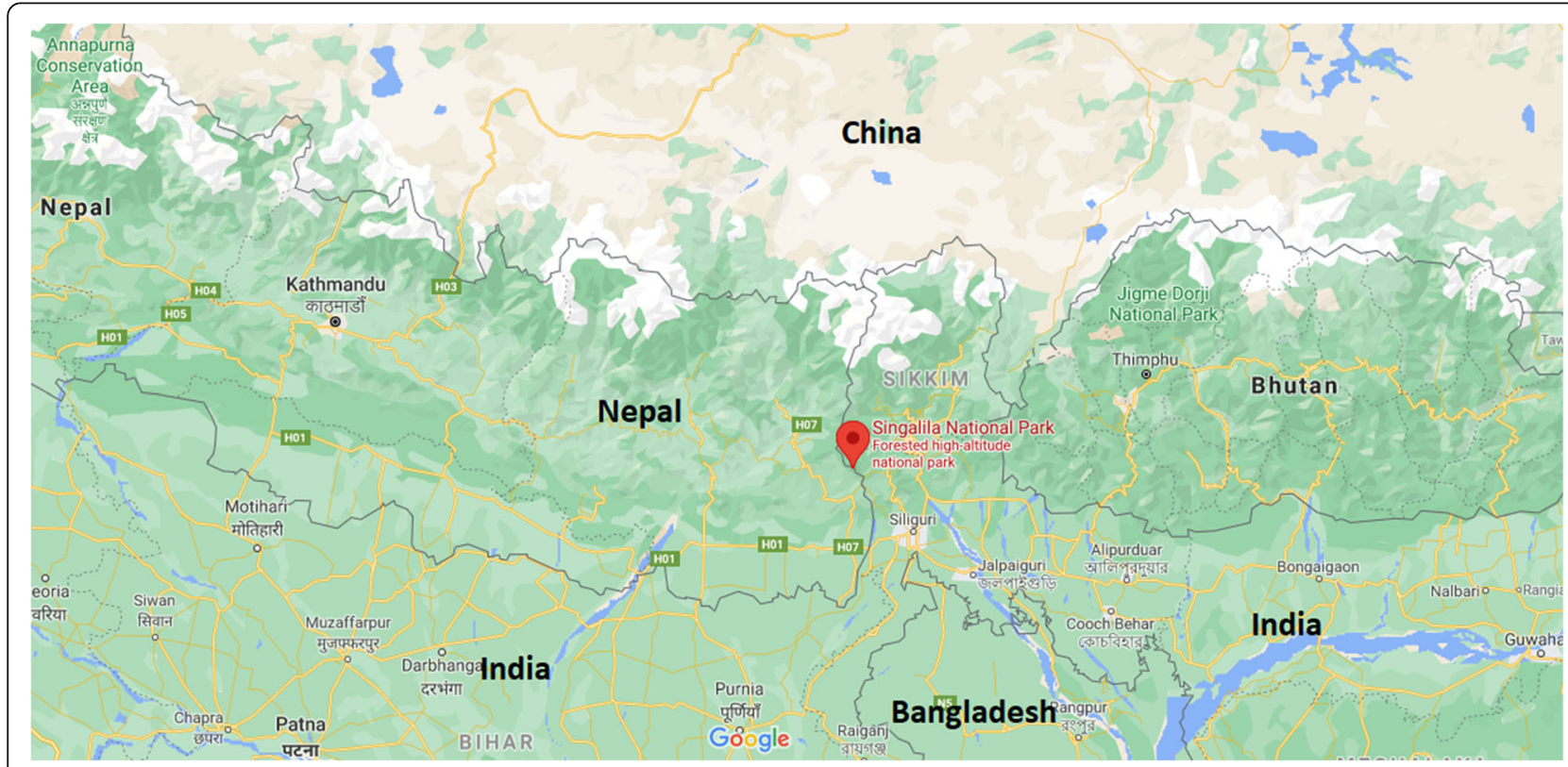

Fig. 1 Location of Singalila National Park at Indo-Nepal border in the Himalayan region 


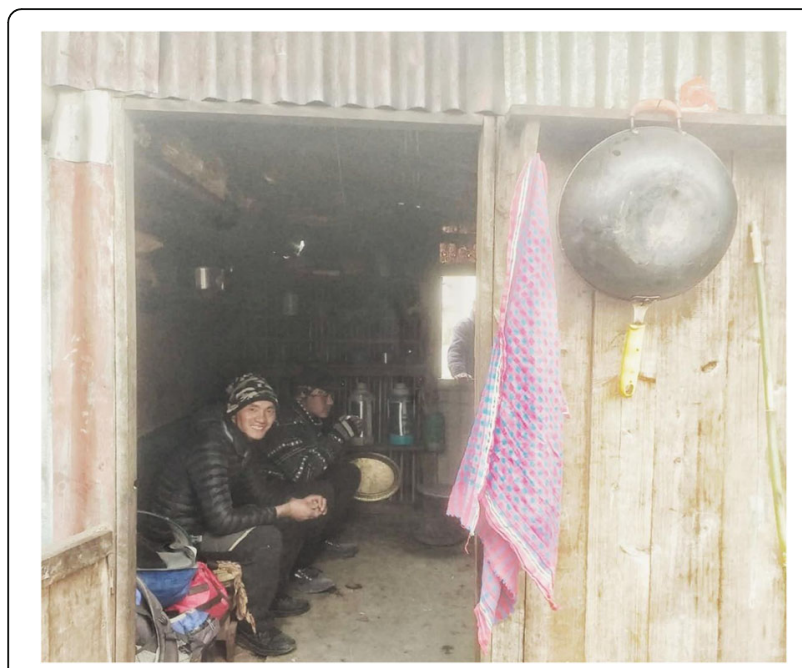

Fig. 2 Raksi selling shop at Bikheybhanjyang, from where samples of freshly prepared raksis were collected adjusted to $230{ }^{\circ} \mathrm{C}$. Helium gas $(99.9 \%)$ was used as carrier gas. Total flow rate and column flow rate were 16.3 $\mathrm{ml} \mathrm{\textrm {min } ^ { - 1 } \text { and } 1 . 2 1 \mathrm { ml } \mathrm { min }}{ }^{-1}$ respectively. Mass spectra were recorded at $5 \mathrm{scan} / \mathrm{s}$ with a scanning rate of 40-650 $\mathrm{m} / \mathrm{z}$. The compounds were identified after comparing the spectral configurations obtained with that of the available mass spectral database. The compounds were detected using library databases like NIST08s.LIB and WILEY8.LIB. The chromatogram (TIC or total ion chromatogram) is based on the intensity of fragments produced by the ionization. Quantification of the amount (area \%) of each compound was done on the basis of peak areas. The data obtained from GCMS analysis were further studied from available literature.

\section{Results and discussion Ethnobiological survey}

In this study, ethnobiological survey helped to collect proper traditional raksi samples from one of the oldest raksi brewer of Bikheybhanjyang (one of the oldest

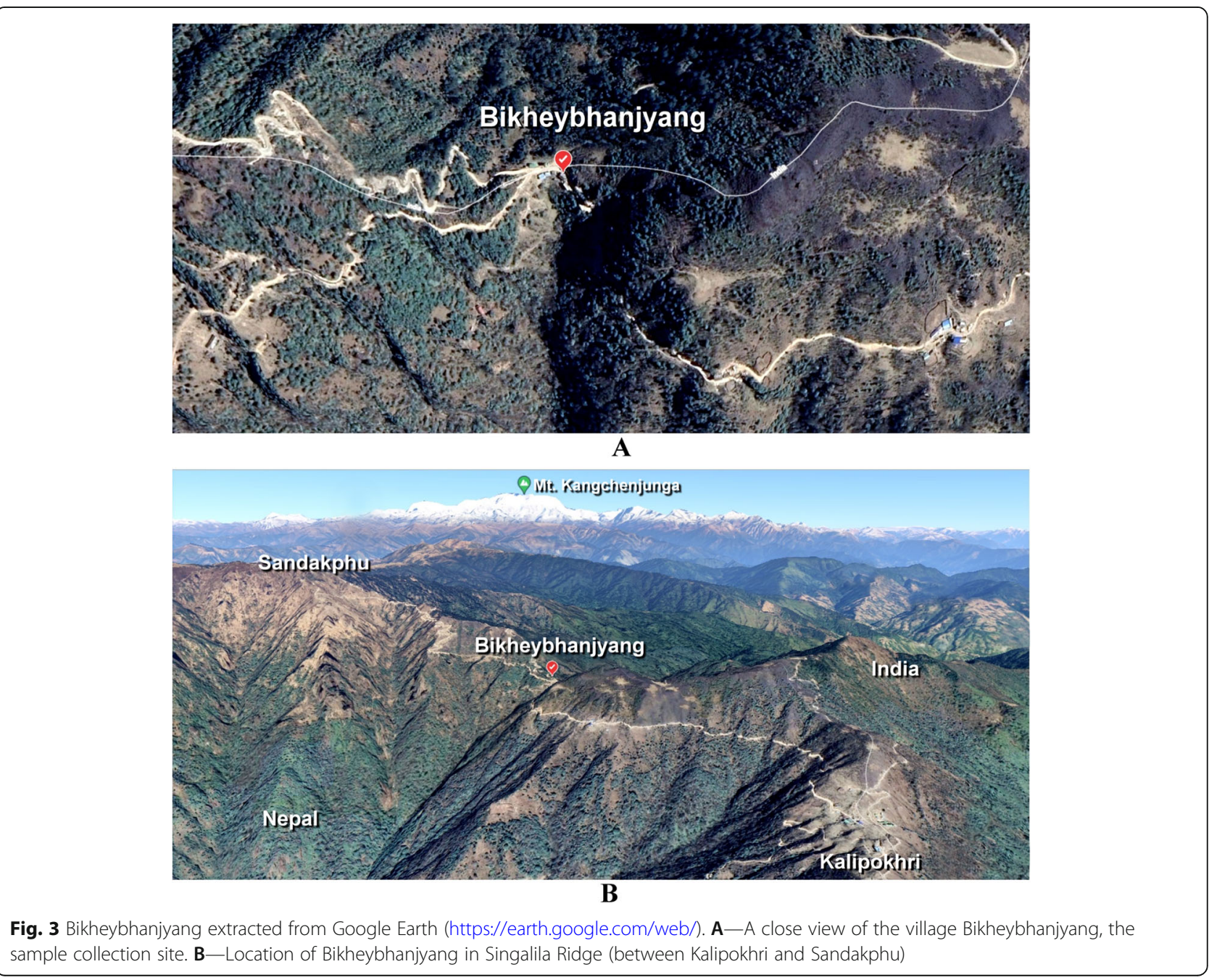




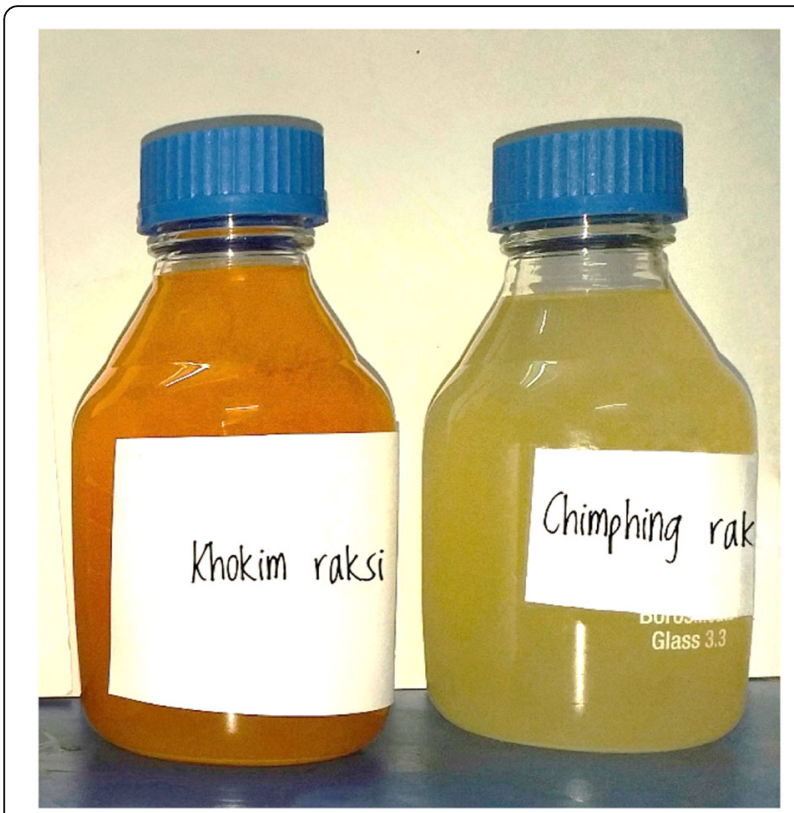

Fig. 4 Samples of raksi KR (left) and CR (right) kept in sterilized laboratorial glass bottles

human settlements in Singalila) and identify two distinct raksi samples: khokim raksi and chimphing raksi. Moreover, all the participants shared their knowledge on ethnomedicinal claims of raksi as cardio-protective, neuroprotective, pain reliever or anti-inflammatory, respiratory illness preventive, and gastro-protective. Furthermore, in this research, scientifically successful tool of metabolomics, i.e., GC-MS metabolite profiling was used to analyze both raksi samples to evaluate the unexplored reports of bioactivity or ethno-medicinal claims in a biochemical way.

\section{GC-MS analysis}

Gas chromatography-mass spectrometry analysis, a successful tool for metabolomics [12], was used in this research to analyze bioactive components of raksi samples and metabolites of the microorganisms involved in raksi fermentation. GC-MS analysis exhibited nineteen peaks for different compounds for the sample KR including bioactive terpenoids, derivatives of bioactive fatty acids (methyl esters of linoleic acid and petroselinic acid), and coumarins (meranzin and auraptene) while CR came out with a total of thirteen compounds which is rich in different amino acid derivatives (amines and peptides) including antibiotic and anti-inflammatory drug compound cyclo(gly-pro) as the major compound. Peak reports for both KR and CR have been included in Table 1.

Bioactivities of raksi compounds against altitude sickness Interestingly, after studying previous literatures on these GC-MS detected compounds, it was found that most of the bioactive components of raksis (Table 1) were reported to prevent diseases and disorders that are cumulatively linked with ailments occurring in high altitude regions, simply known as altitude sickness. This includes a huge number of diseases and disorders, i.e., respiratory disorders like chronic obstructive pulmonary disease (COPD), hypoxia, fatigue, dizziness, loss of energy, and shortness of breath; neurological and psychiatric disorders and diseases like loss of appetite, sleep problems, headache, loss of coordination, cyanosis, confusion and irrational behavior, tightness in the chest, weakness, and vertigo; gastrointestinal problems; pain and inflammation in the body muscle and joints, peripheral edema (swelling of hands, feet, and face); nose bleeding; cardiovascular diseases like high blood pressure, high pulse rate, heart attacks and, at last but least, acute mountain sickness [13]. Regular high altitude ailments and components of raksi reported to prevent them are described below which favorably represent the acceptance of this beverage as a potent high altitude ethnic medicine (on the basis of metabolomics only).

\section{Respiratory illness and raksi components}

Respiratory disorders and more precisely chronic obstructive pulmonary disease (COPD) are considered as the main illness in altitude sickness [13]. Disorders and symptoms like hypoxia, lung injury, bronchitis, asthma, fatigue, dizziness, loss of energy, shortness of breath, and chest pain as a whole are considered as respiratory illnesses. A total of six different raksi components (derivatives of linoleic acid; nootkatone; derivatives of lidocaine; auraptene, calamendiol, etc.) are found to be reported as respiratory illness preventive compounds. Major KR compounds, linoleates [14] and auraptene [15], are reported to prevent hypoxia. According to Takao et al. [16] and Nemmar et al. [17], nootkatone and lidocaine are two lung protective compounds. These two compounds were mainly detected in KR. Moreover, another derivative of lidocaine, lidocaine benzyl benzoate, detected in both KR and CR, is reported as potent bronchodilator [18]. Calamendiol is the only exclusive respiratory protective compound found in $\mathrm{CR}$ which helps to prevent bronchitis (infamous high altitude diseases) and sinusitis [19].

\section{Cardiovascular diseases and raksi components}

It is already described earlier that there are some major cardiovascular diseases reported as high altitude ailments. Sometimes, cardiovascular illness causes life threatening problems to the visitors or tourists after exposure in high altitude environment unlike high altitude residents because, according to principles of ethnoecology described earlier, it is a fact that living at high altitude reduces risk of dying from heart disease [20]. 
Table 1 Components of KR (Khokim raksi extract) and CR (Chimphing raksi extract) detected by GC-MS analysis detected by GC-MS analysis

\begin{tabular}{|c|c|c|c|c|}
\hline $\begin{array}{l}\text { Compound } \\
\text { index }\end{array}$ & Name of compound & $\begin{array}{l}\text { Area\% in } \\
\mathrm{KR}\end{array}$ & $\begin{array}{l}\text { Area\% in } \\
\text { CR }\end{array}$ & Type of compound \\
\hline 1 & Nootkatone & 0.92 & - & Sesquiterpenoid \\
\hline 2 & Copalol & 2.1 & - & Diterpenoid \\
\hline 3 & Squalene & 2.56 & - & Triterpenoid \\
\hline 4 & Geranylgeraniol formate & 1.46 & - & Diterpenoid derivative \\
\hline 5 & Driman-8,11-diol & 2.13 & - & Sesquiterpenoid \\
\hline 6 & Geranyllinalool & - & 4.62 & Diterpenoid \\
\hline 7 & Calamendiol & - & 2.53 & Sesquiterpenoid \\
\hline 8 & Ethyl linoleate & 2.58 & - & $\begin{array}{l}\text { Polyunsaturated omega- } 6 \text { fatty acid } \\
\text { derivative }\end{array}$ \\
\hline 9 & Sandacanol & 0.93 & - & Organic oil \\
\hline 10 & Linoleyl alcohol & 0.26 & - & Fatty alcohol \\
\hline 11 & Methyl palmitate & 2.18 & - & Saturated fatty acid derivative \\
\hline 12 & Methyl linoleate & 20.84 & - & $\begin{array}{l}\text { Polyunsaturated omega- } 6 \text { fatty acid } \\
\text { derivative }\end{array}$ \\
\hline 13 & Methyl petroselinate & 11.96 & - & Unsaturated fatty acid derivative \\
\hline 14 & Methyl stearate & 2.94 & - & Saturated fatty acid derivative \\
\hline 15 & Caprylic triglyceride & 0.44 & - & Natural fatty acids with glycerin \\
\hline 16 & Phenylacetate & - & 6.84 & $\begin{array}{l}\text { Aromatic fatty acid metabolite of } \\
\text { phenylalanine }\end{array}$ \\
\hline 17 & 5-Chlorovaleric acid, 2,5-dichlorophenyl ester & - & 1.14 & Saturated fatty acid derivative \\
\hline 18 & Octyl methacrylate & - & 4.59 & Lipid \\
\hline 19 & Lidocaine & 8.03 & - & Amino amide derivative \\
\hline 20 & Lidocaine benzyl benzoate & 1.56 & 2.51 & Amino amide derivative \\
\hline 21 & $\begin{array}{l}\text { pyrrolo[1,2-a]pyrazine-1,4-dione, hexahydro-or cyclo(gly- } \\
\text { pro) }\end{array}$ & - & 26.47 & Peptide \\
\hline 22 & $\mathrm{~N}, \mathrm{~N}, \mathrm{~N}^{\prime}$-Triethylethylenediamine & - & 8.2 & Amines \\
\hline 23 & Cyclopropanecarboxamide, N-cycloheptyl & - & 17.11 & Amines \\
\hline 24 & 5-Pyrrolidino-2-pyrrolidone & - & 16.77 & Amines \\
\hline 25 & pGlu-phe-pro & - & 5.67 & Peptide \\
\hline 26 & Meranzin & 7.26 & - & Coumarin \\
\hline 27 & Auraptene & 14.44 & - & Monoterpene coumarin \\
\hline 28 & Etiocholanolone glucuronide & 1.17 & - & Steroid \\
\hline 29 & (7R)-cis-anti-cis-Tricyclo[7.3.0.0(2,6)]dodecan-7-ol & - & 2.05 & \\
\hline 30 & Phthalic acid & 16.24 & - & Dicarboxylic acid \\
\hline 31 & |sobutyl tridec-2-yn-1-y| phthalate & - & 1.51 & Dicarboxylic acid \\
\hline
\end{tabular}

Results of this research suggested acceptance of health claims of raksi as a cardio-protective ethnic medicine in the form of a fermented beverage [21]. Reports of fourteen components of both KR and CR revealed raksi's cardiovascular protective activity. Among fatty acid derivatives detected in $K R$, linoleates [22], methyl palmitate [23], methyl petroselinate [24], methyl stearate [25], etc. are reported as cardio-protective agents. Linoleic acid can lower blood cholesterol and prevents coronary heart disease [22]. Cardio-protective agent lidocaine and its derivative lidocaine benzyl benzoate (detected in both $\mathrm{CR}$ and $\mathrm{KR}$ ) prevent hypertension and release high blood pressure [26] which is very important during altitude sickness. Coumarins, the major group of molecules detected in KR (Table 1), are reported to exhibit cardioprotective activities. Monoterpene coumarin auraptene is reported as cardio-protective agent and antihypertensive [27] while coumarin meranzin is reported as antiatherosclerosis [28]. Bioactive terpenoids like nootkatone (antiplatelet) and squalene (controls cholesterol), 
detected in KR, are also reported as cardio-protective compounds [29, 30]. Exclusive CR components pGluphe-pro, being thyrotropin releasing hormone, and calamendiol [19] also prevent cardiovascular diseases. Vasodilation is an important cardiovascular activity that has to occur during hypoxic conditions (lack of oxygen) to allow more blood flow in tissues. Vasodilation decreases blood pressure by increasing blood flow rate through our blood vessels which is very important during physical works (i.e., trekking) in high altitudes. This process also prevents some respiratory ailments in high altitudes. Interestingly, raksi components are rich in potential vasodilators like lidocaine [31], lidocaine benzyl benzoate [26], methyl palmitate [23], and auraptene [27].

\section{Inflammation, pain, and raksi components}

Pain/inflammation and high altitude are closely associated. Pain, nociception, and inflammation in the body muscle and joints, peripheral edema (swelling of hands, feet, and face), etc. are common high altitude problems for high altitude tourists or visitors. Not only raksi, but several other ethnic medicines served as foods or beverages (chhyang, tongba, Rhododendron flower juice or wine, last but not least tea) in many places of Singalila Ridge and neighboring hills to get rid of pains. Interestingly, most of the raksi components of this study, i.e., nootkatone [32], lidocaine [33], methyl palmitate [23], auraptene [34], squalene [12], geranylgeraniol [35], driman-8-11-diol [36], phenylacetate [37], cyclo(gly-pro) [38], and calamendiol [19] are reported as potential antiinflammatory, pain reliever, and anti-nociceptive.

\section{Neurological and psychiatric ailments preventive raksi components}

High altitude neurological and psychiatric ailments may be linked to symptoms like dizziness, mental fatigue, shortness of breath, loss of appetite, sleep problems, headache, loss of coordination, cyanosis, confusion and irrational behavior, tightness in the chest, weakness, and vertigo [13]. KR compounds, i.e., nootkatone [39], auraptene [34], geranylgeraniol [35], and caprylic triglyceride [40], and major CR compound cyclo(gly-pro) [41] are reported as potential neuroprotective components. Major fatty acid components of KR (linoleates and petroselinates) are reported to prevent altitude sickness symptoms like fatigue, dizziness, and vertigo [42-44]. Regarding other KR compounds, lidocaine is reported to prevent intracranial hypertension [45]; major coumarin compound auraptene exhibits all kind of bioactivities against high altitude neurological and psychiatric illness like anxiety, depression, dizziness, and Alzheimer's disease [27]; coumarin meranzin is also an antidepressant [46]; squalene can decrease headache, weakness, and mental fatigue [30]; and caprylic triglyceride [47] is anticonvulsant, bioactive against Alzheimer's disease and can prevent weakness [40]. Jain et al. [19] reported that sesquiterpenoid compound calamendiol (detected in CR) can prevent headache, fatigue, anxiety, moreover, it is an anti-hallucinogen.

\section{Gastroenterological problems and raksi components}

Some of the GC-MS detected components described earlier are known to prevent gastroenterological issues occurring due to exposure of high altitude. Lidocaine (present in KR) and lidocaine benzyl benzoate (detected in both $K R$ and $C R$ ) are two bioactive components that can reduce food intake by reducing hunger (loss of appetite) and increasing satiety rating in human $[48,49]$. Moreover, lidocaine has hepatoprotective activity [50] and lidocaine benzyl benzoate is an antidiabetic agent [51]. Major KR compound auraptene can reduce the loss of appetite potentially [27] which is good for physical activities in high altitude places and it can prevent some digestive problems too [27].

\section{Other bioactivities}

pGlu-phe-pro or pyroglutamyl-phenylalanyl-proline (major CR compound) is a thyrotropin-releasing hormone that increases plasma triiodothyronine levels and triiodothyronine (T3 thyroid hormone) then affects almost every physiological process in the body, including growth and development, metabolism, body temperature, and heart rate [52] which is surely useful in high altitude condition. Interestingly, KR compound nootkatone, is a signature and major molecule of Cyperus rotundus L. plant which exhibits more other potential bioactivities against ailments that are linked with altitude sickness, i.e., laryngitis, tracheitis, pneumonopathy, cough, swelling of throat, nerves weak, headache, dizziness, indigestion, thirst, fever, hypoxia, asthma, and inflammation [53]. Besides high-altitude sickness-related issues described above, these GC-MS detected raksi components can exhibit antioxidant, antibiotic, anticancer, or antitumor activities. Antioxidants are generally compounds produced in the human body and found in foods that help defend cells from damage caused by potentially harmful molecules or free radicals during oxidative stress. Free radicals are harmful when their levels become too high in our body. Multiple illnesses, including diabetes, heart disease, and cancer can be caused by these free radicals. Nootkatone [32], methyl palmitate [23], auraptene [34], squalene [30], geranylgeraniol [54], cyclo(gly-pro) [55], etc. are potential antioxidants molecules of raksi. Some of the compounds are also reported as antibiotic, such as cyclo(gly-pro) [55], lidocaine [56], methyl palmitate [57], nootkatone [58], squalene [30], and driman-8,11-diol [36]. Compounds with anticancer properties are linoleates [59], nootkatone [60], methyl 
palmitate [61], auraptene [34], squalene [30], geranylgeraniol [35], and phenylacetate [37].

\section{Biosynthesis of metabolites present in raksi samples}

Study of metabolite biosynthesis on the basis of GC-MS analysis is a very basic tool and early concept in metabolomics [12]. Types of metabolites detected in raksi and origin of those compounds reveals a number of biosynthesis pathway involved in raksi which either originated from microorganisms involved in raksi fermentation or from the fermentation substrates (millet or rice) and other organic materials used as the starter culture. Biological classification of a compound or study of its chemotaxonomy actually helps reveal the biosynthesis route of that compound [12]. Chemotaxonomy study confirmed the majority of terpenoids, fatty acid derivatives, and coumarins in KR while CR is rich in amines, peptides fatty acid derivatives, and terpenoids as described earlier. Sesquiterpenes (nootkatone, driman-8,11-diol, and calamendiol), diterpenes (copalol, geranylgeraniol formate, and geranyllinalool), a monoterpene (auraptene) and a triterpene (squalene) were detected in raksi (1-7 in Table 1) which are probably derived from either plants (substrate and starter of raksi) or microbial fermentation process, because terpenoid biosynthesis and metabolism is reported in microbial fermentation [62]. Moreover, geranylgeraniol (detected as geranylgeraniol formate) of KR or geranyllinalool of CR plays a role as a common yeast metabolite or fermentation component [63]. Similarly, plant derived or microbial fermentation induced metabolomes revealed fatty acid and lipid biosynthesis and degradation pathways behind occurrence of lipids and fatty acid derivatives (8-18 in Table 1$)$ in raksi, i.e., linoleyl alcohol, sandacanol, ethyl linoleate, methyl palmitate, methyl linoleate, methyl petroselinate, methyl stearate, phenylacetate, octyl methacrylate and 5chlorovaleric acid, and 2,5-dichlorophenyl ester; coumarin biosynthesis pathway behind synthesis of auraptene and meranzin; peptide and amino acid biosynthesis pathway behind synthesis of major CR metabolites (1925 in Table 1) which are chemo-taxonomically peptides or amines, i.e., cyclo(gly-pro); n,n,n'-triethylethylenediamine, cyclopropanecarboxamide n-cycloheptyl; 5pyrrolidino-2-pyrrolidone; and pGlu-phe-pro. Major CR compound and reported Saccharomyces cerevisiae (baker's yeast) metabolite, phenylacetate is also reported as a product of phenylalanine fermentation [64]. Regarding major peptides of $\mathrm{CR}$, pglu-phe-pro is a microbial fermentation derived compound which is also found in different bioactive ethnic fermented foods like Japanese rice wine (sake), different cheese, and soya sauce [65] while 5-pyrrolidino-2-pyrrolidone is reported as a fermentation derived secondary metabolite of Streptomyces [66]. Furthermore, aminobenzoates like lidocaines (lidocaine and lidocaine benzyl benzoate) and steroid like etiocholanolone glucuronide may play role as plant or microbial metabolites if chemotaxonomy is concerned.

Except raksi, the decoction or tea of khokim root (ingredient of khokim raksi or KR) is also used as an ethnomedicine in high altitude which is consumed to treat fever, body ache, muscular pain, etc. [67] and, impressively, a number of compounds have been detected in khokim raksi extract (KR) which are potential antiinflammatory agents or pain relievers. So, reasons behind addition of khokim's root in raksi and pain reliever or anti-inflammatory health claims on khokim raksi are completely valid. Similarly, exclusive chimphing raksi (CR) component, calamendiol [19] and ingredient, i.e., dried fruits of chimphing [67], both have been reported to exhibit bioactivities against sinusitis; thus, the use of chimphing as an ethnomedicine is also justified.

\section{Conclusion}

This is the first study to be reported on ethnobiology and biochemical components of raksi beverage. This article described the ethnomedicinal values of raksi which have been validated by metabolomics. This research also helped to add more scientific value in Himalaya's ethnoecology. Singalila Ridge and adjoining high altitude places of Darjeeling, Sikkim, and Nepal are hubs of ethnobiology which still remain to be studied and explored. Herbal ethno medicines, ethnic foods and ethnic groups of people, and their way of life need to be subjected for future research which will help researchers to discover more and more unveiled biodiversity, anthropology and life science of the Himalayas. Regarding raksi, large peaks of highly bioactive coumarin compound auraptene in khokim raksi and antioxidant and antibiotic agent, peptide compound cyclo(gly-pro) in chimphing raksi, are key outcomes of this research. Studies on bioactivities of metabolites of raksi, and biosynthesis of those components, together helped evaluate the health claims of raksi which conclusively discovered that this ethnic beverage is a potential element of Singalila's ethnoecology. This high altitude fermented beverage is actually a medicine for every possible disorder or disease referred to as highaltitude sickness.

\footnotetext{
Acknowledgements

Authors of this article acknowledge the help they got from Mr. Thendup Tamang (guide), Mr. Soumen Sajjan, Mr. Abhijit Sen, and local inhabitants during collection of raksi samples.
}

\section{Authors' contributions}

SM and MB conceived the idea and designed the protocol. SM, AG, SC, and SS performed collection and laboratory work. SM and MB compiled data and wrote the draft manuscript. All the authors read and approved the manuscript. 


\section{Funding}

Not applicable.

\section{Availability of data and materials}

All data analyzed during this study are included in this article.

\section{Declarations}

\section{Competing interests}

The authors declare that they have no competing interests.

\section{Received: 28 June 2021 Accepted: 30 July 2021}

Published online: 14 August 2021

\section{References}

1. Picon-Reategui E. The food and nutrition of high-altitude populations. The biology of high altitude peoples, vol. 13. Cambridge: Cambridge University Press; 1978. p. 219-50.

2. Ghosh A. An ethnoecological approach to the study of a village. Himachal Pradesh: LAP Lambert Academic Publishing; 2012.

3. Kayser B. Nutrition and high altitude exposure. Int J Sports Med. 1992;13(S 1):S129-32. https://doi.org/10.1055/s-2007-1024616.

4. Anand AC, Sashindran VK, Mohan L. Gastrointestinal problems at high altitude. Trop Gastroenterol. 2006;27(4):147-53.

5. Johnson LM, Hunn ES. Landscape ethnoecology: concepts of biotic and physical space: Berghahn Books; 2010.

6. Tamang JP, Kailasapathy K. Fermented foods and beverages of the world: CRC press; 2010.

7. Pradhan S. Studies on some aspect of the ecology of the red panda Ailurus fulgens, Cuvier 1825 in the Sighalila National park, Darjeeling, India (Doctoral dissertation, University of North Bengal); 1998. https://ir.nbu.ac.in/ bitstream/123456789/1007/18/126676.pdf. Accessed 22 June 2021.

8. Explore Tibet. Raksi- a distilled alcoholic beverage. 2014. https://www. exploretibet.com/blog/raksi-a-distilled-alcoholic-beverage. Accessed 12 June 2021.

9. Dura S. Fermented alcoholic beverages: Jaand, Raksi and Japanese sake. The Science Notes. 2020. https://www.thesciencenotes.com/fermented-a Icoholic-beverages-jaand-raksi-and-japanese-sake/. Accessed 12 June 2021.

10. Ray S, Bagyaraj DJ, Thilagar G, Tamang JP. Preparation of Chyang, an ethnic fermented beverage of the Himalayas, using different raw cereals. J Ethn Foods. 2016;3(4):297-9. https://doi.org/10.1016/j.jef.2016.11.008.

11. Majumder S, Acharyya S, Ghosh A, Chakraborty S, Sarkar S, Saha S, et al. Insights into low biological activity of wax apple (Syzygium samarangense) juice by in vitro phytochemical investigation with special reference to metabolomics. Asian J Nat Prod Biochem. 2021;19(1) https://www.smujo.id/ jnpb/article/view/8308.

12. Majumder S, Ghosh A, Bhattacharya M. Natural anti-inflammatory terpenoids in Camellia japonica leaf and probable biosynthesis pathways of the metabolome. Bull Natl Res Cent. 2020;44(1). https://doi.org/10.1186/s42269020-00397-7.

13. Luks AM. Altitude IIIness. Merck Manuals Professional Edition. 2018. https:// www.merckmanuals.com/professional/injuries-poisoning/altitude-illness/a Ititude-illness. Accessed 19 June 2021.

14. Yamasaki M, Nagatomo T, Matsuyama T, Ikeho Y, Kato E, Nishiyama K, et al. Conjugated linoleic acids inhibit hypoxia inducible factor-1a stabilization under hypoxic condition in human hepatocellular carcinoma cells. J Oleo Sci. 2012;61(9):491-6. https://doi.org/10.5650/jos.61.491.

15. Joghataee S, Mohammad-zadeh M, Amin B, Jafari F, Tondar M, Gholami O. Auraptene has neuroprotective and memory enhancing effects in a rat model of Alzheimer's disease. Neurol Asia. 2020;25(3):353-60.

16. Takao Y, Mikawa K, Nishina K, Maekawa N, Obara H. Lidocaine attenuates hyperoxic lung injury in rabbits. Acta Anaesthesiol Scand. 1996;40(3):318-25. https://doi.org/10.1111/j.1399-6576.1996.tb04439.x.

17. Nemmar A, Al-Salam S, Beegam S, Yuvaraju P, Hamadi N, Ali BH. In vivo protective effects of nootkatone against particles-induced lung injury caused by diesel exhaust is mediated via the NF-KB pathway. Nutrients. 2018;10(3):263. https://doi.org/10.3390/nu10030263.

18. Deshpande DA, Wang WC, Mcllmoyle EL, Robinett KS, Schillinger RM, An SS, et al. Bitter taste receptors on airway smooth muscle bronchodilate by localized calcium signaling and reverse obstruction. Nat Med. 2010;16(11): 1299-304. https://doi.org/10.1038/nm.2237.
19. Jain DK, Gupta S, Jain R, Jain N. Anti-inflammatory activity of $80 \%$ ethanolic extract of Acorus calamus Linn. Leaves in Albino Rats. Res J Pharm Tech. 2010;3:882-4.

20. EurekAlert. Study shows living at high altitude reduces risk of dying from heart disease. American Association for the Advancement of Science (AAAS). 2021. https://www.eurekalert.org/pub_releases/2011-03/uocd-ssl032 511.php. Accessed 19 June 2021.

21. Basnyat B. Raksi Lagyo. Nepali times buzz. https://archive.nepalitimes. com/article/Nepali-Times-Buzz/dhanvantari-raksilagyo,800. Accessed 22 June 2021.

22. Harris WS. Linoleic acid and coronary heart disease. Prostaglandins Leukot Essent Fat Acids. 2008;79(3-5):169-71. https://doi.org/10.1016/j.plefa.2008.09. 005.

23. Hamed AB, Mantawy EM, El-Bakly WM, Abdel-Mottaleb Y, Azab SS. Putative anti-inflammatory, antioxidant, and anti-apoptotic roles of the natural tissue guardian methyl palmitate against isoproterenol-induced myocardial injury in rats. Future J Pharm Sci. 2020;6(1):1-4.

24. Weber N, Richter KD, Schulte E, Mukherjee KD. Petroselinic acid from dietary triacylglycerols reduces the concentration of arachidonic acid in tissue lipids of rats. J Nutr. 1995;125(6):1563-8. https://doi.org/10.1093/jn/125.6.1563.

25. Kurlandsky SB, Stote KS. Cardioprotective effects of chocolate and almond consumption in healthy women. Nutr Res. 2006;26(10):509-16. https://doi. org/10.1016/j.nutres.2006.08.007.

26. Sakai H, Sato K, Yuki K, Chiba Y, Narita M. Denatonium and 6-n-Propyl-2thiouracil, agonists of bitter taste receptor, inhibit contraction of various types of smooth muscles in the rat and mouse. Biol Pharm Bull. 2016;39(1): 33-41.

27. Arabi M, Nasab SH, Lorigooini Z, Boroujeni SN, Mortazavi SM, Anjomshoa M, et al. Auraptene exerts protective effects on maternal separation stressinduced changes in behavior, hippocampus, heart and serum of mice. Int Immunopharmacol. 2021;93:107436. https://doi.org/10.1016/j.intimp.2021.1 07436.

28. Li L, Yu AL, Wang ZL, Chen K, Zheng W, Zhou JJ, et al. Chaihu-shugan-san and absorbed meranzin hydrate induce anti-atherosclerosis and behavioral improvements in high-fat diet ApoE-/-mice via anti-inflammatory and BDNF-TrkB pathway. Biomed Pharmacother. 2019;115:108893. https://doi. org/10.1016/j.biopha.2019.108893.

29. Seo EJ, Lee DU, Kwak JH, Lee SM, Kim YS, Jung YS. Antiplatelet effects of Cyperus rotundus and its component (+)-nootkatone. J Ethnopharmacol. 2011;135(1):48-54. https://doi.org/10.1016/j.jep.2011.02.025.

30. Popa I, Băbeanu N, Niță SU, Popa O, Dinu-Pârvu CE. Squalene-natural resources and applications. Farmacia. 2014;62(5):840-62.

31. Evans GR, Gherardini G, Gürlek A, Langstein H, Joly GA, Cromeens DM, et al. Drug-induced vasodilation in an in vitro and in vivo study: the effects of nicardipine, papaverine, and lidocaine on the rabbit carotid artery. Plast Reconstr Surg. 1997;100(6):1475-81. https://doi.org/10.1097/00006534-1 99711000-00015.

32. Meeran MN, Azimullah S, Adeghate E, Ojha S. Nootkatone attenuates myocardial oxidative damage, inflammation, and apoptosis in isoproterenolinduced myocardial infarction in rats. Phytomedicine. 2021;84:153405. https://doi.org/10.1016/j.phymed.2020.153405

33. Beecham GB, Bansal P, Nessel TA, Goyal A. Lidocaine. 2021. In: StatPearls. Treasure Island (FL): StatPearls Publishing; 2021. PMID: 30969703.

34. Bibak B, Shakeri F, Barreto GE, Keshavarzi Z, Sathyapalan T, Sahebkar A. A review of the pharmacological and therapeutic effects of auraptene. BioFactors. 2019;45(6):867-79. https://doi.org/10.1002/biof.1550.

35. Ho HJ, Shirakawa H, Giriwono PE, Ito A, Komai M. A novel function of geranylgeraniol in regulating testosterone production. Biosci Biotechnol Biochem. 2018;82(6):956-62. https://doi.org/10.1080/09168451.2017.1415129.

36. Jansen BJ, De Groot A. Occurrence, biological activity and synthesis of drimane sesquiterpenoids. Nat Prod Rep. 2004;21(4):449-77. https://doi. org/10.1039/b311170a.

37. Pahan K, Sheikh FG, Namboodiri AM, Singh I. Lovastatin and phenylacetate inhibit the induction of nitric oxide synthase and cytokines in rat primary astrocytes, microglia, and macrophages. J Clin Invest. 1997;100(11):2671-9. https://doi.org/10.1172/JCl119812.

38. Ferro JN, de Aquino FL, de Brito RG, dos Santos PL, Quintans Jde S, de Souza LC, et al. Cyclo(gly-pro), a cyclic dipeptide, attenuates nociceptive behaviour and inflammatory response in mice. Clin Exp Pharmacol Physiol. 2015;42(12):1287-95. https://doi.org/10.1111/1440-1681.12480. 
39. Qi Y, Cheng X, Jing H, Yan T, Xiao F, Wu B, et al. Combination of schisandrin and nootkatone exerts neuroprotective effect in Alzheimer's disease mice model. Metab Brain Dis. 2019;34(6):1689-703. https://doi.org/10.1007/s11 011-019-00475-4.

40. Zhao W, Varghese M, Vempati P, Dzhun A, Cheng A, Wang J, et al. Caprylic triglyceride as a novel therapeutic approach to effectively improve the performance and attenuate the symptoms due to the motor neuron loss in ALS disease. PLoS One. 2012;7(11):e49191. https://doi.org/10.1371/journal. pone.0049191.

41. Guan J, Gluckman PD. IGF-1 derived small neuropeptides and analogues: a novel strategy for the development of pharmaceuticals for neurological conditions. Br J Pharmacol. 2009;157(6):881-91. https://doi.org/10.1111/j.14 76-5381.2009.00256.x.

42. Behan PO, Behan WM, Horrobin D. Effect of high doses of essential fatty acids on the postviral fatigue syndrome. Acta Neurol Scand. 1990;82(3):20916. https://doi.org/10.1111/j.1600-0404.1990.tb04490.x.

43. Warren G, McKendrick M, Pea M. The role of essential fatty acids in chronic fatigue syndrome: a case-controlled study of red-cell membrane essential fatty acids (EFA) and a placebo-controlled treatment study with high dose of EFA. Acta Neurol Scand. 1999;99(2):112-6. https://doi.org/10.1111/j.16000404.1999.tb00667.x

44. Singh D, Tanwar A, Agrawal P. An overview on coriander. J Biomed Pharm Res. 2015;4(2):67-70

45. Bedford RF, Persing JA, Pobereskin L, Butler A. Lidocaine or thiopental for rapid control of intracranial hypertension? Anesth Analg. 1980;59(6):435-7.

46. Liu X, Zhou J, Zhang T, Chen K, Xu M, Wu L, et al. Meranzin hydrate elicits antidepressant effects and restores reward circuitry. Behav Brain Res. 2021; 398:112898. https://doi.org/10.1016/j.bbr.2020.112898.

47. Wlaź P, Socała K, Nieoczym D, Łuszczki JJ, Żarnowska I, Żarnowski T, et al. Anticonvulsant profile of caprylic acid, a main constituent of the mediumchain triglyceride (MCT) ketogenic diet, in mice. Neuropharmacology. 2012; 62(4):1882-9. https://doi.org/10.1016/j.neuropharm.2011.12.015.

48. Murase T, Misawa K, Haramizu S, Minegishi Y, Hase T. Nootkatone, a characteristic constituent of grapefruit, stimulates energy metabolism and prevents diet-induced obesity by activating AMPK. Am J Physiol Endocrinol Metab. 2010;299(2):E266-75. https://doi.org/10.1152/ajpendo.00774.2009.

49. Deloose E, Janssen P, Corsetti M, Biesiekierski J, Masuy I, Rotondo A, et al. Intragastric infusion of denatonium benzoate attenuates interdigestive gastric motility and hunger scores in healthy female volunteers. Am J Clin Nutr. 2017;105(3):580-8. https://doi.org/10.3945/ajcn.116.138297.

50. Thomson PD, Melmon KL, Richardson JA, Cohn K, Steinbrunn W, Cudihee R, et al. Lidocaine pharmacokinetics in advanced heart failure, liver disease, and renal failure in humans. Ann Intern Med. 1973;78(4):499-508. https:// doi.org/10.7326/0003-4819-78-4-499.

51. Straub SG, Mulvaney-Musa J, Yajima H, Weiland GA, Sharp GW. Stimulation of insulin secretion by denatonium, one of the most bitter-tasting substances known. Diabetes. 2003;52(2):356-64. https://doi.org/10.2337/dia betes.52.2.356

52. Shahid MA, Ashraf MA, Sharma S. Physiology, Thyroid Hormone. 2021 May 12. In: StatPearls. Treasure Island (FL): StatPearls Publishing; 2021. PMID: 29763182.

53. Jaiswal Y, Liang Z, Zhao Z. Botanical drugs in Ayurveda and traditional Chinese medicine. J Ethnopharmacol. 2016;194:245-59. https://doi.org/10.1 016/j.jep.2016.06.052.

54. Chandra D, Chaubey P, Parki A, Prakash O, Kumar R, Pant AK. Study on chemical diversity among plant parts of Zingiber chrysanthum and their antioxidant assay. J Biol Active Products Nat. 2017;7(2):107-17. https://doi. org/10.1080/22311866.2017.1326318.

55. Kiran GS, Priyadharsini S, Sajayan A, Ravindran A, Selvin J. An antibiotic agent pyrrolo [1, 2-a] pyrazine-1, 4-dione, hexahydro isolated from a marine bacteria Bacillus tequilensis MSI45 effectively controls multi-drug resistant Staphylococcus aureus. RSC Adv. 2018;8(32):17837-46. https://doi.org/10.103 9/C8RA00820E.

56. Wimberley N, Willey S, Sullivan N, Bartlett JG. Antibacterial properties of lidocaine. Chest. 1979;76(1):37-40. https://doi.org/10.1378/chest.76.1.37.

57. Yff BT, Lindsey KL, Taylor MB, Erasmus DG, Jäger AK. The pharmacological screening of Pentanisia prunelloides and the isolation of the antibacterial compound palmitic acid. J Ethnopharmacol. 2002;79(1):101-7. https://doi. org/10.1016/S0378-8741(01)00380-4.

58. Yamaguchi T. Antibacterial properties of nootkatone against Gram-positive bacteria. Nat Prod Commun. 2019;14(6):1934578X19859999.
59. Beck SA, Smith KL, Tisdale MJ. Anticachectic and antitumor effect of eicosapentaenoic acid and its effect on protein turnover. Cancer Res. 1991; 51(22):6089-93.

60. Yoo E, Lee J, Lertpatipanpong P, Ryu J, Kim CT, Park EY, et al. Antiproliferative activity of A. oxyphylla and its bioactive constituent nootkatone in colorectal cancer cells. BMC Cancer. 2020;20(1):1-2.

61. Harada H, Yamashita U, Kurihara H, Fukushi E, Kawabata J, Kamei Y. Antitumor activity of palmitic acid found as a selective cytotoxic substance in a marine red alga. Anticancer Res. 2002;22(5):2587-90.

62. Schindler J. Terpenoids by microbial fermentation. Ind Eng Chem. 1982; 21(4):537-9. https://doi.org/10.1021/i300008a005.

63. Abbas CA. Production of antioxidants, aromas, colours, flavours, and vitamins by yeasts. In: Yeasts in food and beverages. Berlin, Heidelberg: Springer; 2006. p. 285-334.

64. Vuralhan Z, Morais MA, Tai SL, Piper MD, Pronk JT. Identification and characterization of phenylpyruvate decarboxylase genes in Saccharomyces cerevisiae. Appl Environ Microbiol. 2003;69(8):4534-41. https://doi.org/10.112 8/AEM.69.8.4534-4541.2003.

65. Gazme B, Boachie RT, Tsopmo A, Udenigwe CC. Occurrence, properties and biological significance of pyroglutamyl peptides derived from different food sources. Food Sci Human Wellness. 2019;8(3):268-74. https://doi.org/10.101 6/j.fshw.2019.05.002.

66. Zothanpuia AK, Chandra P, Leo W, Mishra VK, Kumar B, Singh BP. Production of potent antimicrobial compounds from Streptomyces cyaneofuscatus associated with fresh water sediment. Front Microbiol. 2017; 8. https://doi.org/10.3389/fmicb.2017.00068

67. Singh HB, Prasad P, Rai LK. Folk medicinal plants in the Sikkim Himalayas of India. Asian Folkl Stud. 2002;61:295-310.

\section{Publisher's Note}

Springer Nature remains neutral with regard to jurisdictional claims in published maps and institutional affiliations.

Ready to submit your research? Choose BMC and benefit from:

- fast, convenient online submission

- thorough peer review by experienced researchers in your field

- rapid publication on acceptance

- support for research data, including large and complex data types

- gold Open Access which fosters wider collaboration and increased citations

- maximum visibility for your research: over $100 \mathrm{M}$ website views per year

At BMC, research is always in progress.

Learn more biomedcentral.com/submissions 